\title{
Turix, a dynamic mechanistic model for feed evaluation
}

\author{
Luis Manuel Vargas-Villamil ${ }^{1}$, Juan Carlos Ku-Vera ${ }^{2}$, Felipe Vargas-Villamil ${ }^{3}$, Salvador Medina- \\ Peralta $^{4}$, Eric José Avila-Vales ${ }^{4}$, Emilio Manuel Aranda-Ibañez ${ }^{1}$, Leonel Avendaño-Reyes ${ }^{5}$
}

\footnotetext{
${ }^{1}$ Campus Tabasco - Colegio de Postgraduados, Apartado Postal 24, 86500, Cárdenas, Tabasco. México.

${ }^{2}$ Facultad de Medicina Veterinaria y Zootecnia - Universidad Autónoma de Yucatán, México.

${ }^{3}$ Prog. de Matemáticas Aplicadas y Cómputo - Instituto Mexicano del Petróleo, México, D.F. México.

${ }^{4}$ Facultad de Matemáticas - Universidad Autónoma de Yucatán, Mérida, Yucatán. México.

${ }^{5}$ Instituto de Ciencias Agrícolas - Universidad Autónoma de Baja California, Baja California - México.
}

\begin{abstract}
The objective of this study was to use the Turix model (a new mechanistic dynamic model that can be used for feed evaluation under tropical conditions), along with in situ and in vitro sugar cane experimental data from a previous study, to evaluate sugar cane kinetics through estimation of three parameters associated with ruminal bacterial growth: $\mathrm{k}_{\mathrm{M}, \mathrm{SmL}}$, the substrate uptake; $\mathrm{k}_{\mathrm{LM}}$, the bacterial growth from intermediate metabolite; and $\mathrm{Y}_{\mathrm{VFAPFS}}$, the products related to volatile fatty acid yield. Values of these parameters for the whole sugar cane and its neutral detergent fiber (NDF) and acid detergent fiber (ADF) fractions were: a) $\mathrm{k}_{\mathrm{M}, \mathrm{SmL}}, 16.20,50.47$ and $21.97 \mathrm{~mL} \mathrm{~h}^{-1}(\mathrm{mg} \mathrm{M})^{-1}$; b) $\mathrm{k}_{\mathrm{LM}}, 96.00,543.00$ and $1,680.00 \mathrm{~h}^{-1}$; and c) $\mathrm{Y}_{\mathrm{VFA}, \mathrm{FS}}, 1.02,0.40$ and $0.23 \mathrm{~g} \mathrm{~g}^{-1}$, respectively. Results from the model adjustment showed a slow microbial substrate uptake and a low biomass yield for whole sugar cane. The highest substrate uptake was obtained for NDF, while the highest biomass yield was obtained for ADF. The interrelation between the parameters $\mathrm{k}_{\mathrm{M}, \mathrm{SmL}}$ and $\mathrm{Y}_{\mathrm{VFAP}, \mathrm{FS}}$ showed to be important for biological description of microorganism growth and VFAP and biomass production.
\end{abstract}

Key Words: model fitting, parameter estimation, ruminant, simulation, sugar cane

\section{Introduction}

In Latin America, agricultural supplies remain expensive relative to farm-gate prices, and the net effect on production will depend upon input-output price relationship and speed of change for each one (Food and Agriculture Organization, 2008b). Moreover, it has been observed that volatility in grain prices has increased in recent years (Food and Agriculture Organization, 2008a). As a consequence, livestock producers try to diversify their crop-base feeds as a way of finding new ingredients with the same or higher nutritional value (Food and Agriculture Organization, 2008a). In tropical regions, sugar cane (Saccharum officinarum) is a forage resource that can be used during periods of drought or flood, improving production efficiency of ruminants (Preston, 1977). However, some of its limitations as a forage source for ruminants are: a) partial inhibition of rumen cellulolysis (Leng, 1989; Molina, 1990); b) insufficient crude protein content for microbial and animal growth (Preston \& Leng, 1989; Martín, 2004); c) increasing mastication rate (Leng, 1989); d) slower particle reduction (Martín, 2004); and e) increasing retention time of particles in the rumen-reticulum (Muñoz \& Gonzalez, 1998). Ruminal mechanistic models help to understand complex processes such as metabolism of lipids, proteins, peptides and amino acids (Dijkstra et al., 2000; Bauman et al., 2008), as well as fermentation (Nagorcka et al., 2000; Kebreab et al., 2009). These models are designed to obtain biological information from a system that can be used for parameter fitting evaluation or to construct other applied complex models. In Latin America, there are few scientific quantitative data that can be used in mechanistic models. Therefore, it is important to develop models that can use available data from regional animal science laboratories.

The Turix model was developed to study the kinetics of bacterial growth after degradation of feeds commonly consumed by ruminants through the use of parameters with biological meaning. Considering input data from the tropical feed sugar cane, the objective of the present study was to evaluate the ability of the Turix model to obtain parameters with biological significance. Also, the Turix model and its benefits will be evaluated through its biological structure, model testing and sugar cane kinetics.

\section{Material and Methods}

A mechanistic model involving differential equations was developed and tested for kinetic feed evaluation. The evaluation of the model was made through the comparison and evaluation of the parameter value obtained from a 
fitting process when the mechanistic model was used as an objective function. An approximated sum of squares was used as the objective function. The model was used for evaluation of whole sugar cane (WC) and its fractions neutral detergent fiber (NDF) and acid detergent fiber (ADF).

For every evaluation, the model called Turix was fitted to microorganism growth curves to obtain parameters with biological significance. These parameter values were used to compare and evaluate sugar cane kinetics.

Data sets were calculated from in situ residual and in vitro batch culture from previous sugar cane experiments (Aranda Ibañez, 2000). The in vitro experimental data used were calculated from absorbance measurements of ruminal cultures described in a previous study (Aranda Ibañez et al., 2010). The absorbance value of each sample was used to obtain, by means of a simple regression model, the number of microorganisms per milliliter. The regression function was: microbial number (number/mL) $=-0.6411+$ 71.5855 abs. This data and a microbial weight average value obtained from the literature (Baker, 1984, 1990) were used to calculate the average biomass concentration $\left(\mathrm{mg}(\mathrm{mL})^{-1}\right)$ (Table 1).

In all experiments, sugar cane variety was Mex69-290. Also, in situ data sets were used for obtaining degradation rates which were used as variables into the model. The in situ residuals came from nylon bag experiments following a technique described by Ørskov \& McDonald (1979). Two $455 \mathrm{~kg}$ Bos taurus $\times$ Bos indicus sires with rumen cannulas were used. The $\mathrm{WC}$ was cut, mixed with star grass (Cynodon nlenfuensis) and offered at 3\% of their body weight. Previously, WC was mixed with $2 \%$ of urea and minerals.

Mass balance principles (Jacquez \& Simon, 1993) were used to derive a dynamic model for ruminal bacterial growth. The Turix model consisted of ten variables of state and was based on concepts of Monod and Michaelis-Menten (MM) (Panikov, 1995). The model was a transformation from an empirical MM model to a dynamic deterministic mechanistic MM model. Before adapting the model to ruminal conditions, it was compared with empirical MM model at several time points, and its performance was similar to the empirical MM model.

The Turix model was composed of three submodels called feed degradation, bacterial growth, and fermentation (Figure 1). The most important sub-model was bacterial growth since it described the microbial substrate $(\mathrm{Sm})$ uptake and product formation. The feed degradation sub-model described feed degradation until its transformation into $\mathrm{Sm}$. This sub-model was described for three variables, which represented the low, medium and high degradable fractions of the matter evaluated (WC, NDF, and ADF). It was assumed that degradation rate was directly proportional to the amount of feed fraction. When necessary, factional rates $\left(\mathrm{k}_{\mathrm{ND}, \mathrm{Sm}}\right.$, $\mathrm{k}_{\mathrm{NS}, \mathrm{Sm}}$ and $\mathrm{k}_{\mathrm{SC}, \mathrm{Sm}}$ ) were estimated trough regression fitting of WC, NDF and ADF in situ residual curves (Ørskov \& McDonald, 1979). The software used for estimation of degradation parameters was Berkeley Madonna Package v8.0.1, and the Rosenbrock method was performed (Macey et al., 2010).

Table 1 - Calculated microbial biomass concentration $\left(\mathrm{mg} \mathrm{mL}^{-1}\right)$ obtained from in vitro batch culture used for model fitting

\begin{tabular}{|c|c|c|c|c|c|c|}
\hline Time (hours) & Whole sugar cane & Standard deviation & Neutral detergent fiber & Standard deviation & Acid detergent fiber & Standard deviation \\
\hline 0.5 & $0.00667^{1}$ & 0.00785 & 0.00208 & 0.00306 & 0.00229 & 0.00241 \\
\hline 1.0 & 0.01108 & 0.00848 & 0.00317 & 0.00145 & 0.00396 & 0.00323 \\
\hline 1.5 & 0.01752 & 0.01266 & 0.00497 & 0.00273 & 0.00608 & 0.00569 \\
\hline 2.5 & 0.02198 & 0.01356 & 0.00823 & 0.00410 & 0.00658 & 0.00445 \\
\hline 3.0 & 0.02120 & 0.01524 & 0.01179 & 0.00242 & 0.00731 & 0.00263 \\
\hline 3.5 & 0.02642 & 0.01428 & 0.01948 & 0.00543 & 0.00664 & 0.00502 \\
\hline 5.0 & 0.04363 & 0.01168 & 0.03446 & 0.00653 & 0.00720 & 0.00574 \\
\hline 5.5 & 0.04516 & 0.00991 & 0.03593 & 0.00507 & 0.00675 & 0.00566 \\
\hline 6.0 & 0.04946 & 0.00695 & 0.03990 & 0.00465 & 0.00960 & 0.00572 \\
\hline 6.5 & 0.04898 & 0.00845 & 0.04170 & 0.00521 & 0.01027 & 0.00454 \\
\hline 7.0 & 0.05275 & 0.00580 & 0.04471 & 0.00351 & 0.01099 & 0.00493 \\
\hline 7.5 & 0.05333 & 0.00717 & 0.04542 & 0.00387 & 0.01250 & 0.00510 \\
\hline
\end{tabular}

${ }^{1}$ Data calculated from Aranda Ibañez (2000) 
The microbial biomass (M) formation was described for the microbial growth sub-model on the basis of the batch culture growth. This formation process was a function of $\mathrm{Sm}$, intermediate metabolite (L), and M. The sub-model was composed of two sub-processes: irreversible Sm uptake and reversible bacterial growth. The L, in terms of MM models, represented the substrate-enzyme element. Also, in terms of black box compartmental model, L metabolite represents a set of microorganism reactions (Stephanopoulos, 1998). The bacterial fermentation submodel described the ruminal fermentation, i.e., formation of products related to acetate (AcP), propionate $(\mathrm{PrP})$, butyrate $(\mathrm{BuP})$, and valerate $(\mathrm{VaP})$ production, and they were functions of molecular weight, stoichiometry (Murphy, 1984) and products related to volatile fatty acid (VFAP) yield from the fermented substrate $\left(\mathrm{Y}_{\mathrm{VFAPFS}}\right)$. This submodel assumed that $\mathrm{Y}_{\mathrm{M}, \mathrm{FS}}+\mathrm{Y}_{\mathrm{VFAPFS}}=1$, where $\mathrm{Y}_{\mathrm{M}, \mathrm{FS}}$ is the $M$ yield from the fermented substrate (Kerley, 2000).

Three parameters were estimated: $\mathrm{k}_{\mathrm{M}, \mathrm{SmL}}$, determined Sm uptake; $k_{L M}$, bacterial growth from $L$; and $Y_{\text {VFAP,FS }}$ determined VFA-related products (VFAP) from the fermented substrate when VFAP $=\mathrm{VFA}+\mathrm{CO}_{2}+\mathrm{CH} 4$. The Turix model was based on the following assumptions: a) State variables were entities that described behavior of the kinetic system (Panikov, 1995). Thus, Sm, feed and L were represented by glucose. However, it does not imply an absence of other compounds such as cellobiose, cellulose or pentose. b) In vivo kinetics was similar to in vitro and in situ kinetics. c) The system was considered unstructured because changes in composition during bacterial growth were neglected (Panikov, 1995). d) The system was spatially homogenous (perfect mixing), because there was no spatial

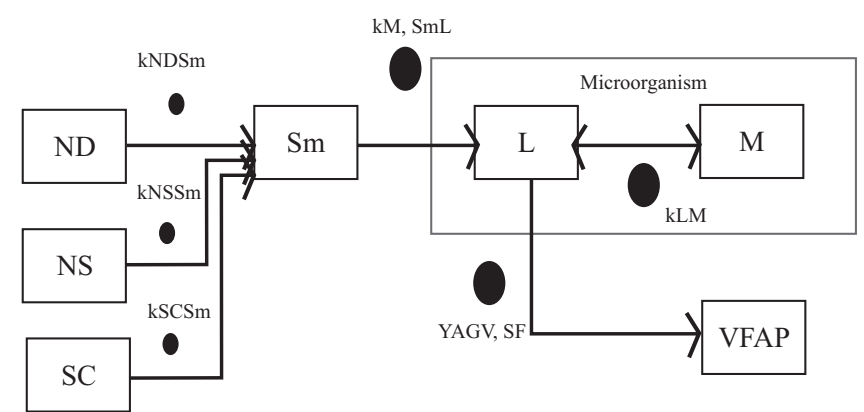

$\mathrm{k}_{\mathrm{M}, \mathrm{SmL}}$ - parameter that determines substrate uptake process; $\mathrm{k}_{\mathrm{LM}}$ - parameter that determines bacterial growth from an intermediate metabolite; $\mathrm{Y}_{\mathrm{VM}}^{\mathrm{MM}}$ - parameter that determines microbial yield of products related to volatile fatty acids; $\mathrm{k}_{\mathrm{NDSm}}$ - low degradable fractional rate; $\mathrm{k}_{\mathrm{NSSm}}$ - medium degradable fractional rate; $\mathrm{k}_{\mathrm{SCSm}}$ - highly degradable fractional rate; ND - low degradable fraction; NS - medium degradable fraction; SC - highly degradable fraction; Sm - microbial substrate; L - intermediate metabolite; M - bacterial biomass; VFAP - products related to volatile fatty acid.

Figure 1 - Schematic representation of microbial system and location of parameters used in the Turix model. gradient (Panikov, 1995). e) Final composition was: $\mathrm{M}+\mathrm{VFAP}$ and VFAP $=\mathrm{VFA}+\mathrm{CO}_{2}+\mathrm{CH}_{4}$. Text and Turix model entity symbols are in Table 2, principal system transactions in Table 3, model notations in Table 4, rates variables from degradation and differential equation initial conditions in Table 5, and mathematical description of Turix model in Table 6. Also, the Turix model simulator can be found at Forio Web site (Vargas-Villamil et al., 2011) (Figure 2).

Parameter values were obtained solving a bounded regression problem involving differential equations

Table 2 - Turix model and text entity symbols

\begin{tabular}{|c|c|c|c|}
\hline Symbol & Entity & Symbol & Entity \\
\hline Ac & Acetate & ND & Degradable fraction \\
\hline $\mathrm{AcP}$ & Products related to Ac & NDF & Neutral detergent fiber \\
\hline $\mathrm{ADF}$ & Acid detergent fiber & NS & $\begin{array}{l}\text { Medium degradable } \\
\text { substrate }\end{array}$ \\
\hline $\mathrm{Bu}$ & Butyrate & $\mathrm{P}$ & Product \\
\hline $\mathrm{BuP}$ & Products related to $\mathrm{Bu}$ & $\operatorname{Pr}$ & Propionate \\
\hline WC & Whole sugar cane & $\operatorname{PrP}$ & Products related to $\mathrm{Pr}$ \\
\hline $\mathrm{D}$ & Degradation & $\mathrm{SC}$ & Highly degradable fraction \\
\hline $\mathrm{F}$ & Fermentation & $\mathrm{Sm}$ & Microbial substrate \\
\hline FS & $\begin{array}{l}\text { Microbial fermented } \\
\text { substrate }\end{array}$ & $\mathrm{Va}$ & Valerate \\
\hline G & Bacterial growth & $\mathrm{VaP}$ & Products related to Va \\
\hline $\mathrm{L}$ & Intermediate metabolite & VFA & Volatile fatty acid \\
\hline M & Bacterial biomass & VFAP & Products related to VFA \\
\hline MW & Molecular weight & & \\
\hline
\end{tabular}

Table 3 - Principal chemical reactions for the Turix model

\begin{tabular}{lccccc}
\hline Transaction & $\begin{array}{c}\text { Principal } \\
\text { substrate }\end{array}$ & Product & Transaction & $\begin{array}{c}\text { Principal } \\
\text { substrate }\end{array}$ & Product \\
\hline NDSm & ND & Sm & ML & ML & L \\
NSSm & NS & Sm & LAcP & L & AcP \\
SCSm & SC & Sm & LBuP & L & BuP \\
SmL & Sm & L & LPrP & L & PrP \\
LM & L & M & LVaP & L & VaP \\
\hline
\end{tabular}

Transaction - chemical reaction.

Table 4 - Turix model notation

\begin{tabular}{|c|c|}
\hline Symbol & Description \\
\hline $\mathrm{C}_{\mathrm{i}}{ }^{1}$ & Concentration of $\mathrm{i},\left(\mathrm{mg} \mathrm{i} \mathrm{mL}^{-1}\right)$. \\
\hline$f_{i}^{1}$ & Fraction of $\mathrm{i}$ in $\mathrm{j},\left(\mathrm{g} \mathrm{i}\left(\mathrm{g} \mathrm{i}^{-1}\right)\right.$ \\
\hline $\begin{array}{l}i_{i, j} \\
k_{j k}\end{array}$ & Fractional rate of the transaction $\mathrm{j}-\mathrm{k},\left(\mathrm{h}^{-1}\right)$. \\
\hline $\mathrm{k}_{\mathrm{i}, \mathrm{jk}}^{\mathrm{jk}}$ & Coefficient of the transaction j-k with respect to i, $\left(\mathrm{mL}(\mathrm{h} \mathrm{mg} \mathrm{i} \mathrm{or} \mathrm{h})^{-1}\right)$ \\
\hline$Q_{i}^{1, n}$ & Quantity of i, $\left(\mathrm{mmol} \mathrm{i}(\mathrm{mL})^{-1}\right)$ \\
\hline $\mathrm{P}_{\mathrm{i}, \mathrm{jk}}$ & Rate of production of $\mathrm{i}$ by transaction $\mathrm{j}-\mathrm{k},\left(\mathrm{mg} \mathrm{i}(\mathrm{h} \mathrm{mL})^{-1}\right)$. \\
\hline $\mathrm{MW}_{\mathrm{i}}$ & Molecular weight of i, (g i). \\
\hline $\mathrm{T}^{\mathrm{T}}$ & Time, (h). \\
\hline $\mathrm{U}_{\mathrm{i}, \mathrm{jk}}$ & Rate of utilization of i by transaction $\mathrm{j}-\mathrm{k},\left(\mathrm{mg}\right.$ i) $(\mathrm{h} \mathrm{mL})^{-1}$. \\
\hline$Y_{i, j}$ & Yield of $\mathrm{i}$ with respect to $\mathrm{j},\left(\mathrm{mol}\right.$ or $\left.\mathrm{g} \mathrm{i}(\mathrm{mol} \text { or } \mathrm{g} \mathrm{j})^{-1}\right)$. \\
\hline
\end{tabular}


Table 5 - Rate variables and differential equation initial values used in the Turix model for sugar cane evaluation

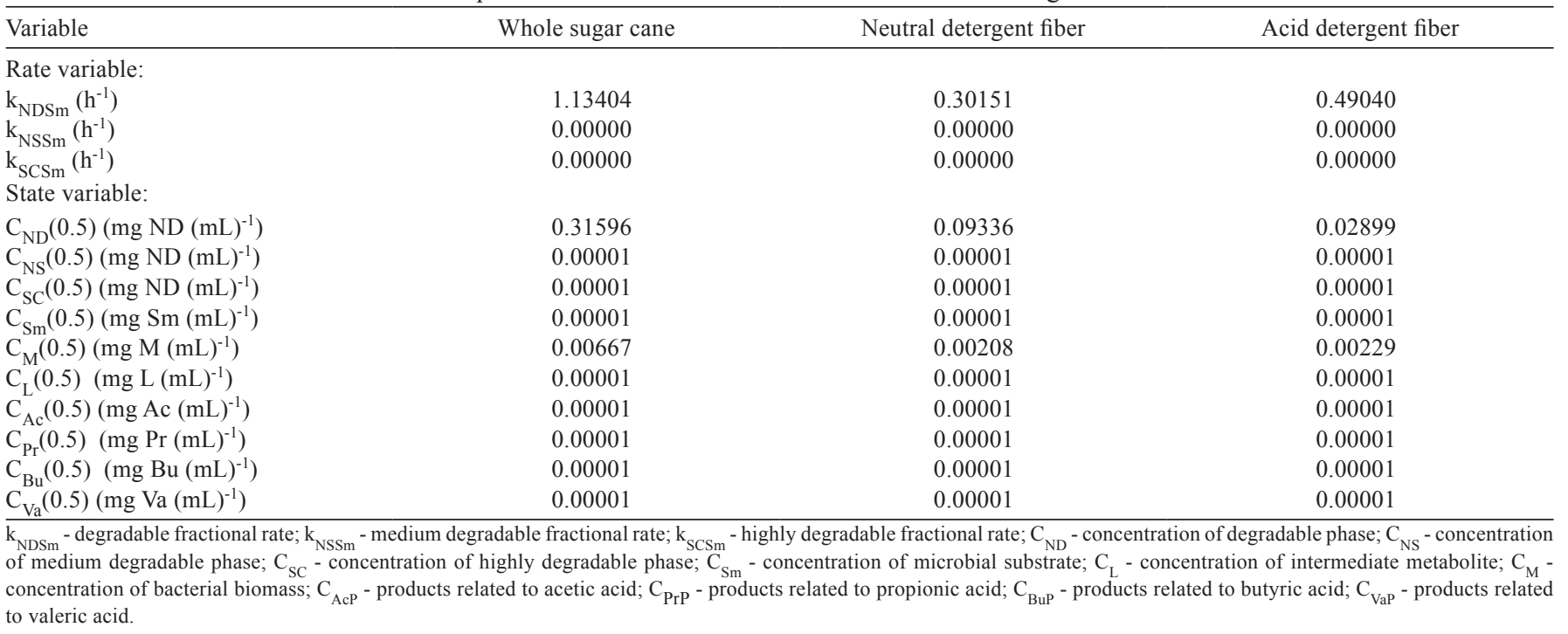

(Equations 1, 2 and 3) using discontinuous culture data shown in Table 1. Equations were as follows:

$\operatorname{minJ}=\sum_{i=1}^{N D}\left(C_{M i}-\tilde{C}_{M i}\right)^{2}$

subject to:

$\frac{d C}{d t}=F\left(C, k_{M, S m L}, k_{L M}, Y_{V F A P, F S}\right)$

$C(0)=C_{0}$

$K_{M, S m L}^{\min }<K_{M, S m L}<K_{M, S m L}^{\max }$

$K_{L M}^{\min }<K_{L M}<K_{L M}^{\max }$

$Y_{V F A P, F S}^{\min }<Y_{V F A P, F S}<Y_{V F A P, F S}^{\max }$

Equation one was a quadratic objective function; equation two was a set of differential equations which described the ruminal microbial system (Appendix, Table 6); ND was the data set size; $i$ was the data index; $\mathrm{C}_{\mathrm{Mi}}$ was the experimental concentration of $\mathrm{M}$; and $\widetilde{\mathrm{C}}_{\mathrm{Mi}}$ was the estimated concentration of $\mathrm{M}$. The regression problem described above was solved using the Berkeley Madonna Package v8.0.1, thorough the Rosenbrock method (Macey et al., 2010). It was initialized using an interval of time $t \in[0.5,10] \mathrm{h}$ and a tolerance of $10^{-3}$.

For assessing the model in predicting the system, a regression technique was used (Tedeschi, 2006) between observed (y) and estimated ( $\mathrm{z}$ ) values by the Turix model for WC and the fractions NDF and ADF. The accuracy was tested by confidence intervals for the intercept $\left(\beta_{0}\right)$ and the slope $\left(\beta_{1}\right)$. The precision, as usual, was tested with the coefficient of determination $\left(\mathrm{R}^{2}\right)$. A significance level of $\alpha=0.05$ was used for the statistical methods.
Table 6 - Turix model description

Feed degradation sub-model:

$\frac{\mathrm{dCND}}{\mathrm{dt}}=-\mathrm{U}_{\mathrm{ND}, \mathrm{NDSm}}$

$\frac{\mathrm{dCNS}}{\mathrm{dt}}=-\mathrm{U}_{\mathrm{NS}, \mathrm{NSSm}}$

$\frac{\mathrm{dCSC}}{\mathrm{dt}}=-\mathrm{U}_{\mathrm{SC}, \mathrm{SCSm}}$

where,

$\mathrm{U}_{\mathrm{ND}, \mathrm{NDSm}}=\mathrm{C}_{\mathrm{ND} \mathrm{kNDSm}}$

$\mathrm{U}_{\mathrm{NS}, \mathrm{NSSm}}=\mathrm{C}_{\mathrm{NS} \mathrm{kNSSm}}$

$\mathrm{U}_{\mathrm{SC}, \mathrm{SCSm}}=\mathrm{C}_{\mathrm{SC} \mathrm{kSCSm}}$

Microbial growth sub-model:

$\frac{\mathrm{dCSm}}{\mathrm{dt}}=\mathrm{P}_{\mathrm{Sm}, \mathrm{NDSm}}+\mathrm{P}_{\mathrm{Sm}, \mathrm{NSSm}}+\mathrm{P}_{\mathrm{Sm}, \mathrm{SCSm}}-\mathrm{U}_{\mathrm{Sm}, \mathrm{SmL}}$

$\frac{\mathrm{dCL}}{\mathrm{dt}}=\mathrm{P}_{\mathrm{L}, \mathrm{ML}}-\mathrm{U}_{\mathrm{L}, \mathrm{LM}}-\mathrm{U}_{\mathrm{L}, \mathrm{LAcP}}-\mathrm{U}_{\mathrm{L}, \mathrm{LPrP}}-\mathrm{U}_{\mathrm{L}, \mathrm{LBuP}}-\mathrm{U}_{\mathrm{L}, \mathrm{LVaP}}$

$\frac{\mathrm{dCM}}{\mathrm{dt}}=\mathrm{P}_{\mathrm{M}, \mathrm{LM}}-\mathrm{U}_{\mathrm{M}, \mathrm{ML}}$

where,

$\mathrm{P}_{\mathrm{Sm}, \mathrm{NDSm}}=\mathrm{U}_{\mathrm{ND}, \mathrm{NDSm}}$

$\mathrm{P}_{\mathrm{Sm}, \mathrm{NSSm}}=\mathrm{U}_{\mathrm{NS}, \mathrm{NSSm}}$

$\mathrm{P}_{\mathrm{Sm}, \mathrm{SCSm}}=\mathrm{U}_{\mathrm{SC}, \mathrm{SCSm}}$

$\mathrm{U}_{\mathrm{Sm}, \mathrm{SmL}}=\mathrm{C}_{\mathrm{M} \mathrm{CSm} \mathrm{kM,SmL}}$

$\mathrm{P}_{\mathrm{L}, \mathrm{ML}}=2\left(\mathrm{U}_{\mathrm{Sm}, \mathrm{SmL}}\right)$

$\mathrm{U}_{\mathrm{L}, \mathrm{LM}}=\mathrm{k}_{\mathrm{LM}} \mathrm{C}_{\mathrm{L}}$

$\mathrm{U}_{\mathrm{L}, \mathrm{LAcP}}=\left(\mathrm{U}_{\mathrm{L}, \mathrm{LM}} \mathrm{Y}_{\mathrm{VFAP}, \mathrm{FS}}\right)\left(\mathrm{Y}_{\mathrm{AcP}, \mathrm{FS}} \mathrm{MW}_{\mathrm{Ac}} / \mathrm{MW}_{\mathrm{Glu}}\right)$

$\mathrm{U}_{\mathrm{L}, \mathrm{LPrP}}=\left(\mathrm{U}_{\mathrm{L}, \mathrm{LM}} \mathrm{Y}_{\mathrm{VFAP}, \mathrm{FS}}\right)\left(\mathrm{Y}_{\mathrm{PrP}, \mathrm{FS}} \mathrm{MW}_{\mathrm{Pr}} / \mathrm{MW}_{\mathrm{Gl}}\right)$

$\mathrm{U}_{\mathrm{L}, \mathrm{LBuP}}=\left(\mathrm{U}_{\mathrm{L}, \mathrm{LM}} \mathrm{Y}_{\mathrm{VFAP}, \mathrm{FS}}\right)\left(\mathrm{Y}_{\mathrm{BuP}, \mathrm{FS}} \mathrm{MW}_{\mathrm{Bu}} / \mathrm{MW}_{\mathrm{Gl}}\right)$

$\mathrm{U}_{\mathrm{L}, \mathrm{LVaP}}=\left(\mathrm{U}_{\mathrm{L}, \mathrm{LM}} \mathrm{Y}_{\mathrm{VFAP}, \mathrm{FS}}\right)\left(\mathrm{Y}_{\mathrm{VaP}, \mathrm{FS}} \mathrm{MW}_{\mathrm{Va}} / \mathrm{MW}_{\mathrm{Gl}}\right)$

$\mathrm{P}_{\mathrm{M}, \mathrm{LM}}=\mathrm{U}_{\mathrm{L}, \mathrm{LM}}$

$\mathrm{U}_{\mathrm{M}, \mathrm{ML}}=\mathrm{U}_{\mathrm{Sm}, \mathrm{SmL}}$

Bacterial fermentation sub-model:

$\frac{\mathrm{dCAcP}}{\mathrm{dt}}=2\left(\mathrm{P}_{\mathrm{AcP}, \mathrm{LAcP}}\right)$

$\frac{\mathrm{dCPrP}}{\mathrm{dt}}=2\left(\mathrm{P}_{\operatorname{PrP}, \mathrm{LPrP}}\right)$

$\frac{\mathrm{dCBuP}}{\mathrm{dt}}=2\left(\mathrm{P}_{\mathrm{BuP}, \mathrm{LBuP}}\right)$

$\frac{\mathrm{dCVaP}}{\mathrm{dt}}=2\left(\mathrm{P}_{\mathrm{VaP}, \mathrm{LVaP}}\right)$

where,

$\mathrm{P}_{\text {VaP,LVaP }}=\mathrm{U}_{\mathrm{L}, \mathrm{LVaP}}$

$\mathrm{P}_{\text {PrP,LPrP }}=\mathrm{U}_{\mathrm{L}, \mathrm{LPrP}}$

$\mathrm{P}_{\text {BuP,LBuP }}=\mathrm{U}_{\mathrm{L}, \mathrm{LBuP}}$

$\underline{\mathrm{P}_{\mathrm{AcP}, \mathrm{LAcP}}}=\mathrm{U}_{\mathrm{L}, \mathrm{LAcP}}$ 


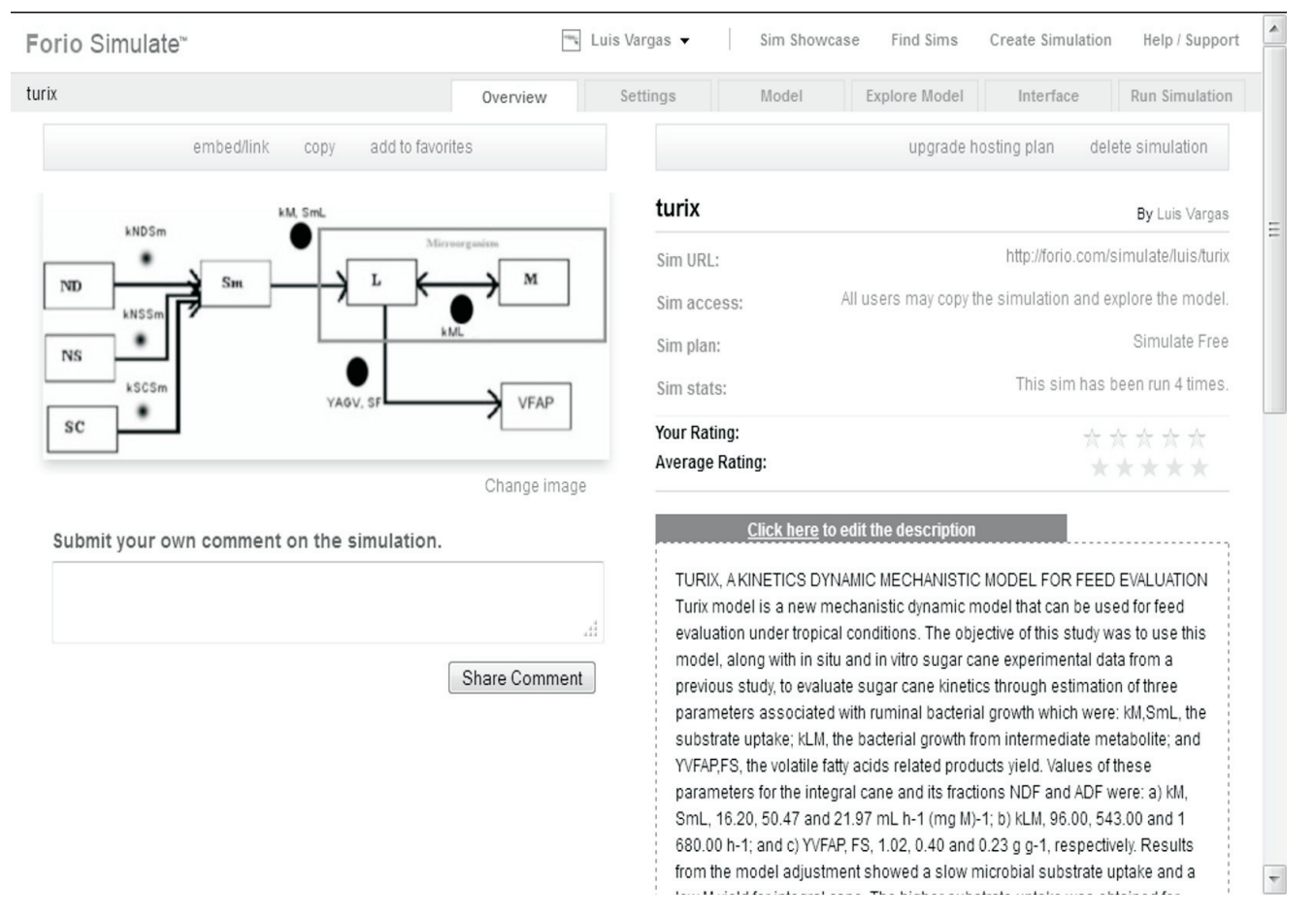

Figure 2 - Overview of Turix model simulator at Forio Web site.

Scientific information was used for evaluation of influence structure for the system elements (state variables, parameter, intermediate variables) as described by Bossel (1994). Also its consequence on behavior of fitting results was evaluated. This kind of evaluation was made for each sub-model because of its importance during the model development (Bossel, 1994).

The fitting convergence, a process that attempts to reach the global minimum by changing values of parameters, was used to test the ability of Turix model to reach only one minimum with experimental data (fitting) and to describe the zone of parameter space for the Turix model. For this, minimum and maximum fitting initial parameter values were changed on incremental ranges (Table 7). After every numerical solution of curve fitting, the square root of the mean square was saved into a matrix for integral evaluation. Finally, the effect of decreasing fitting sampling times was studied, that is, the sampling time in hours was reduced from ten to five and final parameter values were evaluated. The fraction for model testing was NDF.

Table 7 - Maximum and minimum fitting initial parameter values

\begin{tabular}{ll}
\hline Parameter & Fitting parameter value range \\
\hline $\mathrm{k}_{\mathrm{M}, \mathrm{Sm}}\left(\mathrm{mL} \mathrm{h}^{-1}(\mathrm{mg} \mathrm{M})^{-1}\right)$ & $0-3,3-6,6-9,9-12$ \\
$\mathrm{k}_{\mathrm{LM}}\left(1,000 \mathrm{~h}^{-1}\right)$ & $0-0.3,0.3-0.6,0.6-0.9,0.9-1.2,1.2-1.5$, \\
& $1.5-2.5,2.5-3.5,3.5-4.5,4.5-5.5,5.5-6.5$, \\
& $6.5-7.5,7.5-8.5,8.5-9.5$ \\
$\mathrm{Y}_{\text {VFAP, FS }}\left(\mathrm{g} \mathrm{VFAP}(\mathrm{g} \mathrm{FS})^{-1}\right)$ & $0-0.3,0.3-0.6,0.6-0.9$ \\
\hline
\end{tabular}

\section{Results}

The Turix model developed for this study can be parameterized from in situ, in vitro and/or in vivo data obtained in tropical conditions.

Observed values and values estimated by the Turix model for WC, NDF and ADF were compared (Figure 1). Significant linear relationships $(\mathrm{P}<0.05)$ and high accuracies were observed in all cases (WC: $y=0.0055+0.8897 \mathrm{z}$, $\mathrm{F}_{1,17}=535.93, \mathrm{P}<0.0001, \mathrm{R}^{2}=0.9693$; NDF: $\mathrm{y}=0.0011+$ $0.9753 \mathrm{z}, \mathrm{F}_{1,17}=1541.39, \mathrm{P}<0.0001, \mathrm{R}^{2}=0.9891 ; \mathrm{ADF}: \mathrm{y}=$ $\left.0.0027+0.8032 \mathrm{z}, \mathrm{F}_{1,17}=182.34, \mathrm{P}<0.0001, \mathrm{R}^{2}=0.9147\right)$ (Figures 3, 4 and 5). In the case of the NDF treatment, estimation of $95 \%$ confidence intervals for the intercept $\left(\beta_{0}\right)$ contained zero and for the slope $\left(\beta_{1}\right)$ it contained one $\left(-0.0007 \leq \beta_{0} \leq 0.0029,0.9228 \leq \beta_{1} \leq 1.0277\right)$, so the Turix model was considered accurate. For WC and ADF, although their confidence intervals did not contain zero and one, they were narrow and close to those numbers, so the model virtually estimated $\mathrm{WC}$ and ADF values (WC: $\left.0.0021 \leq \beta_{0} \leq 0.0089,0.8086 \leq \beta_{1} \leq 0.9708\right)$; ADF: 0.0014 $\left.\leq \beta_{0} \leq 0.0039,0.6777 \leq \beta_{1} \leq 0.9287\right)$.

A RMS depression that had dimensions determined by ranges of the following parameters can be observed (Figure 6): $\mathrm{k}_{\mathrm{M}, \mathrm{SmL}}$ from 9.00 to $15.00 \mathrm{~mL} \mathrm{~h}^{-1}\left(\mathrm{mg} \mathrm{M}^{-1}\right.$, $\mathrm{k}_{\mathrm{LM}}$ from 0.00 to $6500 \mathrm{~h}^{-1}$ and $\mathrm{Y}_{\mathrm{VFAP}, \mathrm{FS}}$ from 50.00 to $0.90 \mathrm{~g}$ VFAP (g FS) $)^{-1}$. Only one global minimum depression was 
found in this study. Fitting method will be able to find real parameter values when it can converge to a global minimum with a sound model. This can only be achieved with a single error depression (Givens \& Hoeting, 2005; Bates \& Watts, 2007).

In an attempt to reduce the fitting sample times by half, the parameter with the highest variation was $\mathrm{k}_{\mathrm{LM}}(-99 \%)$. The parameter $Y_{\mathrm{VFAP}, \mathrm{SS}}(+4.00 \%)$ had small variations, followed by $\mathrm{k}_{\mathrm{M}}$, $\mathrm{SmL}(-0.48 \%)$, which presented the lowest variation. The RMS changed from 0.0028 to 0.16 . This pattern was

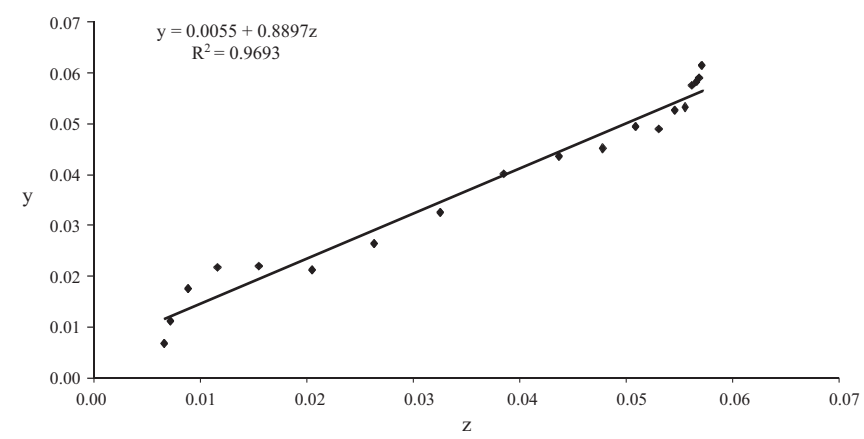

Figure 3 - Relationship between estimated (z) and observed (y) values of whole sugarcane.

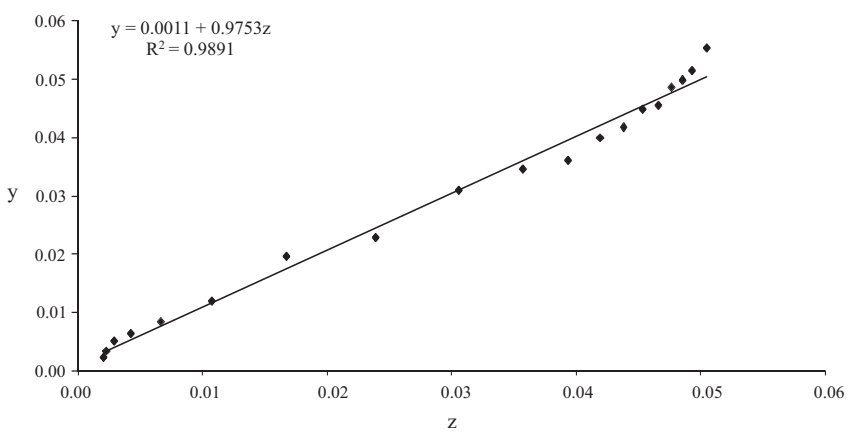

Figure 4 - Relationship between estimated (z) and observed values (y) of neutral detergent fiber.

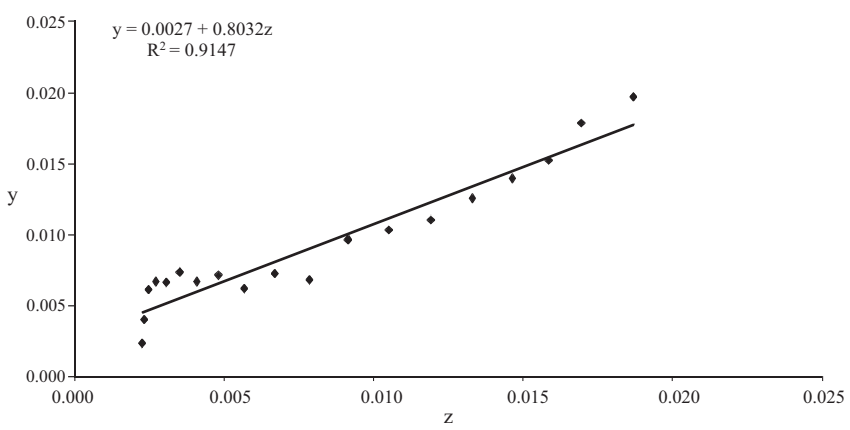

Figure 5 - Relationship between estimated (z) and observed (y) values of acid detergent fiber. close to the results for extreme fitting initial $\mathrm{k}_{\mathrm{M}}$, $\mathrm{SmL}$ and $Y_{\text {VFAP, FS }}$ parameter values (data not included), where values showed consistency, except for the parameter $\mathrm{k}_{\mathrm{LM}}$.

The Turix model structure shows that the fitted value of $\mathrm{k}_{\mathrm{M}, \mathrm{SmL}}$ (Table 8) can be considered as an indicator of sugar cane Sm uptake. For this, it could be considered that WC $\left(16.20 \mathrm{~mL} \mathrm{~h}^{-1}(\mathrm{mg} \mathrm{M})^{-1}\right)$ had a lower Sm uptake compared with NDF $\left(50.47 \mathrm{~mL} \mathrm{~h}^{-1}\left(\mathrm{mg} \mathrm{M}^{-1}\right)\right.$ or ADF $\left(21.97 \mathrm{~mL} \mathrm{~h}^{-1}(\mathrm{mg} \mathrm{M})^{-1}\right.$. The low value of uptake observed in WC was probably a result of an interaction with the low Sm uptake of cell content. The ADF had a lower Sm uptake $\left(21.97 \mathrm{~mL} \mathrm{~h}^{-1}(\mathrm{mg} \mathrm{M})^{-1}\right)$ than NDF. This could be interpreted as a higher Sm uptake for hemicellulose than for the ADF fraction.

The $\mathrm{Y}_{\text {VFAP FS }}$ value for WC was near one $\left(\mathrm{g}\right.$ VFAP $\left(\mathrm{g} \mathrm{FS}^{-1}\right)$, followed by NDF $\left(0.40 \mathrm{~g} \mathrm{VFAP}(\mathrm{g} \mathrm{FS})^{-1}\right)$ and $\mathrm{ADF}(0.23 \mathrm{~g} \mathrm{VFAP}$ $\left(\right.$ ( FS $\left.^{-1}\right)$ (Table 8). The $\mathrm{Y}_{\mathrm{VFAP}, \mathrm{FS}}$ value for NDF suggested that the $Y_{\mathrm{VFAP}, \mathrm{FS}}$ value for cell content could be similar to WC. The results obtained for NDF and ADF fractions suggested that $\mathrm{Y}_{\mathrm{VFAP}, \mathrm{FS}}$ value for hemicellulose could be near NDF (Hemicellulose $=$ NDF - ADF). In this study, $\mathrm{k}_{\mathrm{M}}$, $\mathrm{SmL}$ decreased from 1.02 to $0.23 \mathrm{~mL} \mathrm{~h}^{-1}(\mathrm{mg} \mathrm{M})^{-1}$ as a consequence of the type of substrate.

The WC had lower Sm uptake value $\left(16.20 \mathrm{~mL} \mathrm{~h}^{-1}\right.$ $(\mathrm{mg} \mathrm{M})^{-1}$ ) than NDF and ADF fractions (Table 8), but also had the highest empirical $\mathrm{Sm}$ uptake in terms of maximum velocity $\left(\mathrm{V}_{\max }=2.9 \mathrm{~g} \mathrm{Sm} \mathrm{h}^{-1}(\mathrm{~g} \mathrm{M})^{-1}\right)$ followed by $\operatorname{NDF}\left(\mathrm{V}_{\max }=1.5 \mathrm{~g} \mathrm{Sm} \mathrm{h}^{-1}(\mathrm{~g} \mathrm{M})^{-1}\right)$ and $\operatorname{ADF}\left(\mathrm{V}_{\max }=\right.$ $\left.0.30 \mathrm{~g} \mathrm{Sm} \mathrm{h}^{-1}(\mathrm{~g} \mathrm{M})^{-1}\right)$. In terms of Turix model structure in

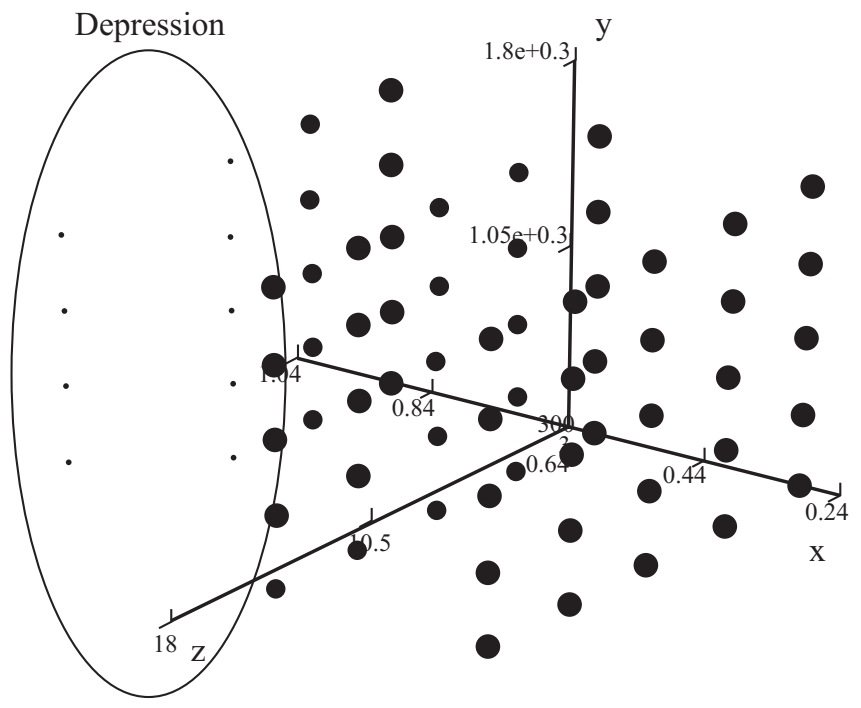

The size of circles represents root mean square values. $\mathrm{Z}$-axis - $\mathrm{k}_{\mathrm{M}, \mathrm{SmL}}$ value; $\mathrm{x}$ axis $-\mathrm{Y}_{\mathrm{AGV}, \mathrm{FS}}$ value; $\mathrm{y}$ axis $-\mathrm{k}_{\mathrm{LM}}$ value.

Figure 6 - Down section of a 3D representation of behavior of the value of root mean square of the parameter space values. 
a ruminal system, a high WC $\mathrm{Y}_{\mathrm{VFAP}, \mathrm{FS}}$ value would increase the concentration of VFA products at the expense of the $M$ concentration (high $\mathrm{V}_{\max }$ value). The NDF intermediate $\mathrm{Y}_{\mathrm{VFAP}, \mathrm{FS}}$ value would produce an intermediate synthesis of $\mathrm{M}$ (medium $\mathrm{V}_{\max }$ value), and a high synthesis of $\mathrm{M}$ at the expense of VFA synthesis as a consequence of $Y_{\text {VFAP, FS }}$ value would produce a low empirical $\mathrm{Sm}$ uptake (low $\mathrm{V}_{\text {max }}$ value). The differences between Turix and empirical uptake values could be explained by a decrease in the velocity of reactions as a consequence of high Sm concentrations.

The model testing found that $\mathrm{k}_{\mathrm{LM}}$ was an indicator with high variation during fitting, decrease of sample time and extreme initial parameter values. This $\mathrm{k}_{\mathrm{LM}}$ parameter characteristic did not help to find a unique set of parameter values with a biological meaning. The value of RMS for NDF and ADF was 1.98E-03, and was lower than 3.96E-03 for $\mathrm{WC}$, indicating that $\mathrm{WC}$ exhibited less accurate fitting.

\section{Discussion}

The Turix model was designed to evaluate microorganism growth kinetics through biologicalsignificance parameter values, which were used to compare and evaluate sugar cane kinetics. Evaluation of sugar cane was through the evaluation of $\mathrm{WC}$ and their fractions NDF and ADF as an example of kinetic feed evaluation. This is important because differences among WC, NDF and ADF fractions describe their contribution to the total kinetics of sugar cane. For that, the system evaluation consisted of two parts: a) fitting of the model to in vitro sugar cane curves for $\mathrm{WC}, \mathrm{NDF}$, and $\mathrm{ADF}$; and $\mathrm{b}$ ) comparison of kinetic parameters among WC, NDF, and ADF. Also, the model assumes a non steady state that is valuable for dynamic systems. This is essential for intraday evaluations of forage intake, digestibility, degradation and ruminal fermentation in ruminants feeding on low to medium quality forage, a common situation in tropical conditions (Carey et al., 1993).

Table 8 - Fitted parameter values for whole sugar cane, neutral detergent fiber and acid detergent fiber treatments

\begin{tabular}{|c|c|c|c|}
\hline Parameter & $\begin{array}{c}\text { Whole sugar } \\
\text { cane }\end{array}$ & $\begin{array}{c}\text { Neutral } \\
\text { detergent fiber }\end{array}$ & $\begin{array}{l}\text { Acid detergent } \\
\text { fiber }\end{array}$ \\
\hline $\mathrm{k}_{\mathrm{M}, \mathrm{SmL}}\left(\mathrm{mL} \mathrm{h}^{-1}(\mathrm{mg} \mathrm{M})^{-1}\right)$ & 16.20 & 50.47 & 21.97 \\
\hline $\mathrm{k}_{\mathrm{LM}}^{\mathrm{M}, \mathrm{SmL}}(\mathrm{h})^{-1}$ & $9.60 \mathrm{E}+01$ & $5.43 \mathrm{E}+02$ & $1.68 \mathrm{E}+03$ \\
\hline$Y_{\mathrm{VFAP}}\left(\mathrm{g} \operatorname{VFAP}(\mathrm{g} \mathrm{FS})^{-1}\right)$ & 1.02 & 0.40 & 0.23 \\
\hline RMS & $3.96 \mathrm{E}-03$ & $1.98 \mathrm{E}-03$ & $1.98 \mathrm{E}-03$ \\
\hline
\end{tabular}

$\mathrm{k}_{\mathrm{M} \text {. }}$ - parameter that determines behavior of subprocess of microbial substrate uptake; $\mathrm{k}_{\mathrm{LM}}$ - parameter that determines behavior of subprocess of bacterial growth; $\mathrm{Y}_{\mathrm{VFAP}, \mathrm{FS}}$ - parameter that determines microbial yield of volatile fatty acid production; RMS - root mean square.
During the model development process, a mechanistic dynamic compartmental model (Bates \& Watts, 2007) based on Michael-Mentens kinetics was assumed. These concepts were based on the Law of Conservation of Mass, which states that reactants and products are in equilibrium (Brown et al., 2008). This is true for chemical reactions (Berg et al., 2008) and bacterial cultures (Russell \& Baldwin, 1979; Russell et al., 1981). The principle is fundamental to obtain bacterial reaction rates and its kinetic parameters (Panikov, 1995). In this study, kinetics was considered to be a set of rates and mechanisms of any chemical, physical, or biological process (Panikov, 1995). Thus, it was possible to construct a ruminal model to describe flows of materials of the substrate (feed) into products (biomass) and VFA.

The $\mathrm{k}_{\mathrm{M}, \mathrm{SmL}}$ parameter was a microbial substrate (Sm) uptake indicator since it described uptake of Sm. Nevertheless, degraded material that escaped from nylon bag could not be completely degraded (Uden \& Van Soest, 1984), and it is possible that this material may be degraded during the time that it remains in ruminal fluid. If degradation were slower or similar to $\mathrm{Sm}$ uptake, it could be reflected in the value of the parameter $\mathrm{k}_{\mathrm{M}, \mathrm{SmL}}$. The parameters $\mathrm{k}_{\mathrm{LM}}$ and $\mathrm{Y}_{\mathrm{VFAPFS}}$ described bacterial behavior efficiency through synthesis of Monod-equivalent variable M (Panikov, 1995) and yield (Y) (Hespell \& Bryant, 1979; Soest, 1994) related to VFA production. These two parameters were closely related because energy is obtained as a consequence of fermentation of $\mathrm{Sm}$, which depends on synthesis of M (Ørskov et al., 1968; Hespell \& Bryant, 1979 ) and vice versa. Both parameters are important for evaluation of ruminal efficiency (Kerley, 2000). Using the Turix model, it was found that $\mathrm{M}$ efficiency increased the biomass flow from the rumen by up to 1.50 times (data not included). The increase in M efficiency was a consequence of different simulated dilution rates as observed for in vitro experiments (Kerley, 2000). In the Turix model, the Y Y VFAP,FS yields allowed to describe total flux behavior of VFA products (VFAP) and its individual fluxes. In the Turix model, Murphy constants (Kennedy, 2005) were used to describe individual fluxes of VFA. The use of these constants was reasonable, since they were obtained using forage with similar composition to that used in Latin America.

In the bacterial fermentation sub-model, a VFAP total flux was represented by fluxes more commonly found in ruminal fermentation: acetate $(\mathrm{AcP})$, propionate $(\mathrm{PrP})$, butyrate (BuP), and valerate (VaP) (Ørskov et al., 1968; Murphy, 1984). These fluxes were function of some parameters, which were obtained from literature (Murphy, 1984). Thus, model prediction was limited by the underlying assumptions made for those studies. However, the use of 
these parameters was reasonable since production of VFA varied according to ruminal conditions, so it was impossible to obtain an accurate prediction (Brown et al., 2008). Because of its complexity, modeling ruminal digestion is a difficult problem that is still open to question (Bannink et al., 1997).

Root mean square (RMS) (Givens \& Hoeting, 2005; Bates \& Watts, 2007) is often used as a measure of goodness-of-fit. The surface generated by RMS in the SPV does not represent a flat surface because there is always a random component in the data. This surface represents the behavior of one objective function that the authors wanted to minimize.

The fitting procedures require minimizing the objective function so a unique set of parameters close to the zone where the global minimum is located can be obtained. Since parameters of a model during fitting procedures are unknown, values that associate an abstract model to real world data can acquire estimated values with a wide range of real numbers. Initial values of parameters will depend on particular circumstances of a system and on the method used (Givens \& Hoeting, 2005; Bates \& Watts, 2007). From a biological and modeling theoretical perspective, SPS would represent imprecision in searching for real values of parameters and global minimum.

The cone form of the depression obtained from the Turix model suggests an increase of the probability to find the global minimum during the convergence, when the value of the parameters approaches the beginning of the depression. Minimum and maximum fitting parameter initial values, in our case, were not important, while parameter values were inside the depression. For this particular case, experimental data determined the form of the RMS surface (Bates \& Watts, 2007). Therefore, they can change with different data. It is necessary to work with many sets of experimental data to have a better idea of the data tendencies during convergence and to evaluate changes in RMS surface. This first evaluation of Turix parameters fitting allows us to expect the presence of only one depression; however, a second evaluation of the model is required when sufficient understanding of its proper performance is achieved.

The results suggested that values of the parameters $\mathrm{k}_{\mathrm{M}}$, ${ }_{S m L}$ and $Y_{\text {VFAP, FS }}$ obtained in different environments can be used with certain confidence and under similar situations to those reported in this study. The $\mathrm{k}_{\mathrm{M}}$, SmL and $\mathrm{Y}_{\mathrm{VFAP}, \mathrm{FS}}$ parameters showed enough independence and stability to be used for diet evaluation because they keep consistent final value during fitting procedure regardless of the value of the other parameters, decreasing sample time and extreme initial values. The variations in the $\mathrm{k}_{\mathrm{LM}}$ parameter value did not affect $\mathrm{k}_{\mathrm{M}}$, SmL and $\mathrm{Y}_{\mathrm{VFAP}, \mathrm{FS}}$ parameter performance and could be fixed to an arbitrary number during curve fitting. For that, an arbitrary initial differential equation $\mathrm{k}_{\mathrm{LM}}$ value of $250 \mathrm{~h}^{-1}$ is recommended for parameter fitting during diet evaluation until a new scientific evaluation is accomplished. This is based on an unpublished evaluation where it was found that this value does not affect the other fitted parameter value.

The sugar cane fiber fractions (NDF, ADF) have been considered as causes of poor results in animal performance experiments (Muñoz \& Gonzalez, 1998). Fraction kinetics could give other perspective about these poor results. The Sm uptake could be described as a function of $\mathrm{M}$ concentration per hour (Kajikawa et al., 1997; Kajikawa $\&$ Masaki, 1999). Hence, this kind of uptake described for these authors will be called empirical Sm uptake in this study. For the Turix model, Sm uptake was a function of the product of M and Sm concentration per hour. Empirical and Turix Sm uptake indicators were calculated from Turix numerical solution (data not included).

The sugar cane had different Sm uptake values for every fraction. This has been reported in controlled experiments with purified glucose and cellulose (Kajikawa et al., 1997; Kajikawa \& Masaki, 1999). The Sm uptake variation for ruminal mixed cultures found in scientific literature ranged

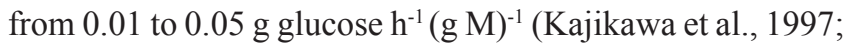
Kajikawa \& Masaki, 1999), which is far from the lowest value obtained in this study, $0.30 \mathrm{~g} \mathrm{Sm} \mathrm{h}^{-1}(\mathrm{~g} \mathrm{M})^{-1}$ )(data not included). However, there are reports of higher rates of uptake $\left(0.88 \mathrm{~g} \mathrm{glucose}^{-1}(\mathrm{~g} \mathrm{M})^{-1}\right.$ (Reijenga et al., 2000). The evidence presented above shows that $\mathrm{Sm}$ uptake changed by substrate, by fraction of feed and by microorganisms, among others. Because of these variations, it is necessary to evaluate feeds under the same conditions of those used by the producer.

Kerley (2000) found a decrease in the $\mathrm{Y}_{\mathrm{VFAP}, \mathrm{FS}}$ value from 0.79 to $0.54 \mathrm{~g}$ VFAP ( $\mathrm{g} \mathrm{FS})^{-1}$ as the dilution rate increased from 0.025 to $0.20 \mathrm{VFAP}(\mathrm{g} \mathrm{FS})^{-1}$. The sugar cane had wider range of $Y_{V F A P, ~ F S}$ values than those reported in the literature, but lower mean value $\left(0.55\right.$ VFAP $\left(\mathrm{g} \mathrm{FS}^{-1}\right)$ than fiber diets $\left(0.64\right.$ VFAP $\left.(\mathrm{g} \mathrm{FS})^{-1}\right)($ Kerley, 2000). Also, an increase was found in $Y_{\text {VFAP, FS }}$ values from 0.023 to $1.02 \mathrm{~g}$ VFAP $\left(\mathrm{g} \mathrm{FS}^{-1}\right.$ when the maximum concentration of $\mathrm{Sm}$ increased from 0.019 to $0.22 \mathrm{mg} \mathrm{Sm} \mathrm{mL}^{-1}$ in culture (data not included).

The interrelation of parameters $k_{\mathrm{M}, \mathrm{SmL}}$ and $\mathrm{Y}_{\mathrm{VFAP}}$, FS showed to be important for biological description of microorganism growth and production of VFAP and M. In this sense, the Turix model could be a tool for evaluation of substrates or diets due to nutritional conditions (dilution rate, intake, etc.). Also, when the parameters are used for 
simulation of biological processes, it is possible to describe and evaluate biological relationships between system elements determined by the Turix parameters (product and substrate rates, empirical uptake, etc.).

It was assumed that fiber causes difficulties on intake and that fast fermentation of soluble carbohydrates presented in cell content depresses degradation (Preston, 1977; Ruiz, 2001). Also, fiber may produce poor animal growth performance (Alvarez \& Preston, 1976; Ferreiro et al., 1977). The results of this study allowed for a quantitative analysis of some sugar cane kinetic characteristics that had not been studied previously. The fraction that seems to affect kinetic behavior of WC was cell contents. The WC had low estimated values for Sm uptake, indicating that a large carbohydrate fraction was dissolved in extra cellular media and washed out from the rumen without being captured by any bacteria. Some authors discovered that after intake, dilution rate was increased and, therefore, the material in the rumen washes out undigested material (Baker \& Car, 1999). It is important to know the amount of substrate which is degraded in the rumen for appropriate diet evaluation studies. In this case, the Turix model is an interesting tool to evaluate some quantitative parameters with biological significance or which are used as a submodel in a nutritional diet evaluation model.

\section{Conclusions}

The form of the surface of errors facilitates the estimation of a unique set of parameters and determining a global minimum for the particular scenario of experimental data set used. Parameters $\mathrm{k}_{\mathrm{M}}$, SmL and $\mathrm{Y}_{\mathrm{VFAP}, \mathrm{FS}}$, unlike parameter $\mathrm{k}_{\mathrm{LM}}$, show enough independence and stability to be used for diet evaluation because they keep consistent final value during the fitting procedure regardless of the value of the other parameters, decrease of sample time and extreme initial values. The authors of the present study recommend excluding parameter $\mathrm{k}_{\mathrm{LM}}$ from diet evaluations until new studies are accomplished. Whole sugarcane treatment has a lower microbial substrate uptake and production of biomass than the ones for neutral detergent fiber or acid detergent fiber fractions but high formation of volatile fatty acids. The results of this study allow for a quantitative analysis of sugar cane kinetic characteristics that have not been studied previously.

\section{Acknowledgements}

The authors thank the financial support obtained from CONACYT in project 33722-B.

\section{References}

ALVAREZ, F.J.; PRESTON, T.R. Studies on urea utilization in sugar cane diets: Effects of level. Tropical Animal Production, v.1, p.98-104, 1976.

ARANDA IBAÑEZ, E.M. Utilización de la caña de azúcar en la alimentación de rumiantes. 2000. 90p. Thesis (Doctorate in Veterinarian Science) - Universidad Nacional Autónoma de México, Mexico.

ARANDA IBÁÑEZ, E.M.; MENDOZA MARTÍNEZ, G.D.; RAMOS JUÁREZ, J.A. et al. Efeito de enzimas fibrolíticas sobre a degradação microbiana ruminal da fibra de cana-de-açúcar. Ciência Animal Brasileira, v.11, n.3, p.488-495, 2010.

BAKER, S.K. The rumen as an ecosystem. In: MOIR, R.J.; BAKER, S.K. (Eds.). Ruminant physiology: Concepts and consequences. Proceedings of a symposium held at University of Western Australia. Australia: School of Agriculture (Animal Science), University of Western Australia, 1984. p.149-160.

BAKER, S.K. Allometry and the implications of cell size in the rumen microbial population. In: AKIN, D.E. (Ed.). Microbial and plant opportunities to improve lignocellulose utilization by ruminants: proceedings of the Tri-National Workshop Microbial and Plant Opportunities to Improve Lignocellulose Utilization by Ruminants. New York: Elsevier, 1990. p.253-264.

BAKER, S.K.; CAR, N.G. Growth rate hysteresis in the rumen microbial population. South African Journal of Animal Science, v.29, n.ISRP, p.83-84, 1999.

BANNINK, A.; DE VISSER, H.; KLOP, A. et al. Causes of inaccurate prediction of volatile fatty acids by simulation models of rumen function in lactating cows. Journal of Theoretical Biology, v.189, n.4, p.353-366, 1997.

BATES, D.M.; WATTS, D.G. Nonlinear regression analysis and its applications. California: John Wiley \& Sons, 2007. 365p. Available at: $<$ http://books.google.com/books?id=m5I_AQAAIAAJ $>$. Accessed on: Mar. 12, 2013.

BAUMAN, D.E.; PERFIELD, J.W., II.; HARVATINE, K.J. et al. Regulation of fat synthesis by conjugated linoleic acid: Lactation and the ruminant model. Journal of Nutrition, v.138, n.2, p.403-409, 2008.

BERG, J.M.; STRYER, L.; TYMOCZKO, J.L. Bioquímica. 6. Reverté, 2008. 1026p. Available at: <http://books.google.com/books?id= HRr4MNH2YssC $>$. Accessed on: Mar. 12, 2013.

BOSSEL, H. Modeling and simulation. Wellesley: A.K. Peters, 1994. 484p. Available at: <http://books.google.com/books?id=CMeg WN6NsBAC $>$. Accessed on: Mar. 12, 2013.

BROWN, T.L.; LEMAY, H.E.; BURSTEN, B.E. Chemistry: the central science. Pensilvania: Pearson Prentice Hall, 2008. 1117p. Available at: $<$ http://books.google.com/books?id=18xaAAAAYAAJ $>$. Accessed on: Mar. 12, 2013.

CAREY, D.A.; CATON, J.S.; BIONDINI, M. Influence of energysource on forage intake, digestibility, in-situ forage degradation, and ruminal fermentation in beef steers fed medium-quality brome hay. Journal of Animal Science, v.71, n.8, p.2260-2269, 1993.

DIJKSTRA, J.; GERRITS, W.J.J.; BANNINK, A. et al. Modelling lipids metabolism in the rumen. In: McNAMARA, J.P.; FRANCE, J.; BEEVER, D.E. (Eds.). Modelling nutrient utilization in farm animals. Wallingford: CABI Pub., 2000. p.25-36.

FERREIRO, H.M.; SUTHERLAND, T.M.; WILSON, A. et al. Fattening cattle with sugar cane: A comparison of different supplements. Tropical Animal Production, v.2, p.309-314, 1977.

FOOD AND AGRICULTURE ORGANIZATION - FAO. Food outlook: Global market analysis. Economic and Social Department. (June). FAO, 2008a. 95p. Available at: <ftp://ftp.fao.org/docrep/ fao/010/ai466e/ai466e00.pdf> Accessed on: Mar. 12, 2013.

FOOD AND AGRICULTURE ORGANIZATION - FAO. Food outlook: Global market analysis. Economic and Social Department. (November). FAO, 2008b. 99p. Available at: <ftp://ftp.fao.org/ docrep/fao/011/ai474e/ai474e00.pdf> Accessed on: Mar. 12, 2013. 
GIVENS, G.H.; HOETING, J.A. Computational statistics. Michigan: Wiley-Interscience, 2005. Available at: <http://books.google.com/ books?id=ByDvAAAAMAAJ $>$. Accessed on: Mar. 12, 2013.

HESPELL, R.B.; BRYANT, M.P. Efficiency of rumen microbialgrowth - Influence of some theoretical and experimental factors

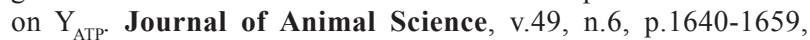
1979.

JACQUEZ, J.A.; SIMON, C.P. Qualitative theory of compartmentalsystems. Siam Review, v.35, n.1, p.43-79, 1993.

KAJIKAWA, H.; AMARI, M.; MASAKI, S. Glucose transport by mixed ruminal bacteria from a cow. Applied and Environmental Microbiology, v.63, n.5, p.1847-1851, 1997.

KAJIKAWA, H.; MASAKI, S. Cellobiose transport by mixed ruminal bacteria from a cow. Applied and Environmental Microbiology, v.65, n.6, p.2565-2569, 1999.

KEBREAB, E.; DIJKSTRA, J.; BANNINK, A. et al. Recent advances in modeling nutrient utilization in ruminants. Journal of Animal Science, v.87, n.14, p.E111-E122, 2009.

KENNEDY, P.M. Particle dynamics. In: DIJKSTRA, J.; FORBES, J.M.; FRANCE, J. (Eds.). Quantitative aspects of ruminant digestion and metabolism. 2. Wallingford: CABI Pub., 2005. p.123-156.

KERLEY, M.S. Feeding for enhanced rumen function. 61st Minnesota Nutrition Conference Papers. Bloomington, Minnesota: University of Minnesota, 2000.

LENG, R.A. Restricciones metabólicas para la utilización de caña de azúcar y sus subproductos para el crecimiento y producción de leche en rumiantes mayores. Seminar-workshop on Intensive Systems for Tropical Livestock Production. Cali, Colombia, 1989. p.23-54.

MACEY, R.; OSTER, G.; ZAHNLEY, T. Berkeley Madonna user's guide version 8.3.18. Berkeley: Department of Molecular and Cellular Biology, University of California, 2010.

MARTÍN, M.P.C. The feeding of cattle with sugar cane and its byproducts. San José de las Lajas: EDICA, 2004. 193p.

MOLINA, A. Forage potential of sugar cane for fattening cattle. Beef production in the tropics. In: VALDÉS, G. (Ed.). Producción de carne en el trópico. San José de las Lajas: EDICA, 1990. p.235-269.

MUÑOZ, E.; GONZALEZ, R. Integral sugar cane to stimulate ad libitum intake of coarse feeds by cows. Cuban Journal of Agricultural Science, v.32, n.1, p.33-40, 1998.

MURPHY, M.R. Modeling production of volatile fatty acids in ruminants. In: BALDWIN, R.L.; BYWATER, A.C. (Eds.) Modeling digestion and metabolism. Proceeding of the 2nd International Workshop, 1984. Davis: University of California, 1984. p. 100.

NAGORCKA, B.N.; GORDON, G.L.R.; DYNES, R.A. Toward a more accurate representation of fermentation in mathematical model of the rumen. In: McNAMARA, J.P.; FRANCE, J.; BEEVER, D.E. (Eds.). Modelling nutrient utilization in farm animals. Wallingford: CABI Pub., 2000. p.37-48.
ØRSKOV, E.R.; FLATT, W.P.; MOE, P.W. Fermentation balance approach to estimate extent of fermentation and efficiency of volatile fatty acid formation in ruminants. Journal of Dairy Science, v.51, n.9, p.1429-1435, 1968.

ØRSKOV, E.R.; MCDONALD, I. Estimation of protein degradability in the rumen from incubation measurements weighted according to rate of passage. Journal of Agricultural Science, v.92, p.499-503, 1979.

PANIKOV, N.S. Microbial growth kinetics. London: Chapman and Hall, 1995. 378p. Available at: <http://books.google.com.mx/ books?id=6Z8X01OjY6kC $>$. Accessed on: Mar. 12, 2013.

PRESTON, T.R. Nutritive value of sugar cane for ruminants. Tropical Animal Production, v.2, p.125-142, 1977.

PRESTON, T.R.; LENG, R.A. Setting livestock production systems to available resources: Basic and applied aspects of the new approach to ruminant nutrition in the tropics. Cali, Colombia: Consultorías para el Desarrollo Rural Integrado en el Trópico (CONDRIT) Ltda, 1989. 312p.

REIJENGA, K.A.; SNOEP, J.L.; WESTERHOFF, H.V. Control of metabolic dynamics: how the frequency of glycolytic oscillations in Saccharomyces cerevisiae is controlled by glucose transport BTK2000. In: HOFMEYR, J.H.S.; ROHWER, J.M.; SNOEP, J.C. (Eds.) BioThermoKinetics 2000. Stellenbosch, South Africa: Stellenbosch University Press, 2000. 319p. Available at: <http:// books.google.com/books/about/Animating_the_Cellular_Map. html?id=uopCAAAACAAJ $>$ Accessed on: Mar. $12,2013$.

RUIZ, P. In situ digestion of sugar cane and fiber fractions. 2001. 180p. Dissertation (Master Degree in Livestock) - Programa de Ganaderia, Colegio de Postgraduados, Montecillo.

RUSSELL, J.B.; BALDWIN, R.L. Comparison of substrate affinities among several rumen bacteria - a possible determinant of rumen bacterial competition. Applied and Environmental Microbiology, v.37, n.3, p.531-536, 1979.

RUSSELL, J.B.; COTTA, M.A.; DOMBROWSKI, D.B. Rumen bacterial competition in continuous culture - Streptococcus bovis versus Megasphaera elsdenii. Applied and Environmental Microbiology, v.41, n.6, p.1394-1399, 1981.

SOEST, P.J.V. Nutritional ecology of the ruminant. 2. Ithaca: Comstock Pub., 1994. 476p. Available at: <http://books.google com/books?id=-mwUu6PL1UgC >. Accessed on: Mar. 12, 2013.

STEPHANOPOULOS, G. Material balance and data consistency. In: STEPHANOPOULOS, G.; ARISTIDOU, A.A.; NIELSEN, J. (Eds.). Metabolic engineering: principles and methodologies. San Diego: Academic Press, 1998. p.115-146.

TEDESCHI, L.O. Assessment of the adequacy of mathematical models. Agricultural Systems, v.89, n.2-3, p.225-247, 2006.

UDEN, P.; VAN SOEST, P.J. Investigations of the in situ bag technique and a comparison of the fermentation in heifers, sheep, ponies and rabbits. Journal of Animal Science, v.58, n.1, p.213-221, 1984.

VARGAS-VILLAMIL, L.M.; KU-VERA, J.; VARGAS-VILLAMIL, F. et al. Turix, a kinetics dynamic mechanistic model for feed evaluation (Overview). 2011. Available at: $<\mathrm{http} / / /$ forio.com/ simulate/luis/turix/overview/>. Accessed on: Nov. 25, 2011. 